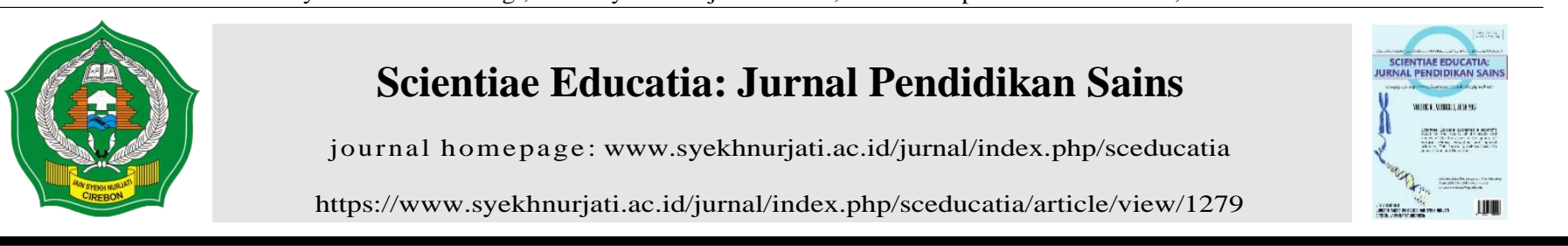

\title{
Pengaruh Pembelajaran Berbasis Web terhadap Motivasi dan Hasil Belajar Siswa Kelas X SMA Negeri Paguyangan pada Mata Pelajaran Fisika Pokok Bahasan Suhu Dan Kalor
}

\author{
Fatwa Aji Kurniawan \\ Program Studi Fisika Universitas Ma'arif NU Kebumen, Jawa Tengah, 54316, Indonesia

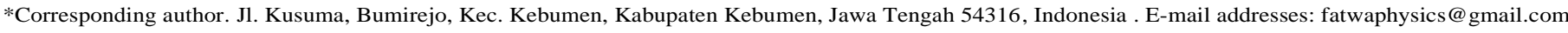

a r t i c l e i n f o

Article history:

Received 24 January 2017

Received in revised form 11 April

2017

Accepted 13 April 2017

Available online June 2017

Keywords:

learning outcome

motivation

web-based learning

physics

Kata Kunci:

hasil belajar

motivasi

pembelajaran berbasis website

fisika

\begin{abstract}
a b s t r a c t
Research that aims to find out the effect of web-based learning on the motivation and physics learning outcome of students in a topic of temperature and heat has been done. This research was conducted by using an experimental quasi-method with non-equivalent groups pretest-posttest experimental design. The population was all the tenth-grade students of Paguyangan senior high school. Samples $(n=48)$ were taken using purposive sampling technique. The research data in the form of cognitive learning outcome obtained from the test and the students' attitude scores obtained from the observation sheet. The result of t-test showed that the increasing of motivation to learn of experimental class at 24.58 was higher than the control class which only amounted to 15.34 . The mean value of posttest at 74.03 for the experimental class with $87.5 \%$ of students achieved the boundary value whereas the mean value for the control class 71.25 and the number of students who achieved the boundary value only $75 \%$. The result of t-test showed that the increasing of learning outcome for the experimental class at 26.66 was higher than the control class which only amounted to 20.10 .

Telah dilakukan penelitian yang bertujuan untuk mengetahui pengaruh pembelajaran berbasis web terhadap motivasi dan hasil belajar siswa pada mata pelajaran fisika pokok bahasan suhu dan kalor. Penelitian ini menggunakan metode quasi eksperimen dengan model non-equivalent groups pretestposttest experimental. Populasi yang digunakan yaitu seluruh siswa kelas X SMAN Paguyangan. Sampel $(n=48)$ diambil menggunakan teknik purposif sampling. Data penelitian berupa hasil belajar kognitif diperoleh dari tes dan skor sikap siswa diperoleh dari lembar observasi. Hasil uji t menunjukan peningkatan motivasi belajar kelas ekperimen sebesar 24,58 lebih tinggi daripada kelas kontrol yang hanya sebesar 15,34. Rerata nilai posttest untuk kelas ekperimen 74,03 dengan 87,5\% siswa mencapai KKM sedangkan rerata nilai posttest untuk kelas kontrol 71,25 dan jumlah siswa yang mencapai KKM hanya $75 \%$. Hasil uji t menunjukan peningkatan hasil belajar kelas eksperimen sebesar 26,66 lebih tinggi daripada kelas kontrol yang hanya 20,10.
\end{abstract}

\section{Pendahuluan}

Fisika merupakan ilmu pengetahuan yang umumnya memiliki banyak konsep dan prinsip yang bersifat abstrak sehingga menyebabkan siswa kesulitan dalam menginterpretasikannya secara tepat dan tidak samar-samar. Kesulitan tersebut membuat motivasi dan hasil belajar fisika siswa rendah jika dibandingkan pelajaran yang lain. Hal tersebut diperkuat oleh hasil wawancara dengan guru fisika di SMA Negeri Paguyangan bahwa ketika proses pembelajaran sebagian besar siswa diam seperti kesulitan tetapi tidak mau bertanya dan ketika diberi permasalahan tidak dapat menyelesaikannya.

Konsep fisika yang abstrak tersebut sebenarnya dapat dideskripsikan menggunakan kata-kata, gambar, diagram dan lainlain. Oleh karena itu, kemampuan guru dalam membuat deskripsi pengetahuan yang didukung dengan kemampuan siswa dalam memahaminya sangat berperan dalam keberhasilan mencapai tujuan pembelajaran.

Praktikum atau eksperimen menurut beberapa kajian teori dan hasil penelitian merupakan strategi yang tepat digunakan dalam pembelajaran fisika karena siswa diberi kesempatan untuk merasakan bagaimana konsep dan prinsip fisika yang mereka pelajari tersebut diterapkan. Sebagai contoh, adalah sangat mudah bagi guru untuk menjelaskan bahwa titik beku air pada suhu $0^{\circ} \mathrm{C}$ dan titik didih air pada suhu $100^{\circ} \mathrm{C}$. Tetapi bagi siswa hal tersebut seolah-olah hanya sebuah cerita dari guru yang perlu dihafalkan untuk persiapan ulangan harian. Padahal manfaat yang besar akan diperoleh jika siswa diberi pengetahuan bagaimana cara mengukur suhu. Dengan demikian siswa akan mengetahui sendiri titik beku dan titik didih air. 
Kenyataan di lapangan menunjukan bahwa tidak semua materi fisika dapat dipraktikumkan, hal ini karena setiap materi dibatasi oleh waktu belajar. Peraturan dan tuntutan kurikulum mengharuskan materi tiap pokok bahasan selesai tepat waktu. Kegiatan praktikum membutuhkan waktu belajar yang lebih banyak sehingga jika semua materi dipraktikumkan akan berakibat pada mata pelajaran yang lain tidak mendapatkan jam belajar.

Berbagai upaya telah dilakukan untuk mengurangi kendala tersebut yaitu dengan membagikan CD pembelajaran interaktif baik yang berisi buku digital, modul digital maupun laboratorium virtual (Sutarman, 2016). Tetapi usaha tersebut belum sepenuhnya efektif karena siswa harus memiliki perangkat komputer atau laptop untuk menjalankan aplikasinya. Siswa juga tidak dapat menggunakan aplikasi tersebut di setiap tempat dan setiap saat ketika perangkat komputer atau laptop tidak dibawa . Selain itu guru tidak dapat mengontrol secara langsung sejauh mana siswanya mempelajari materi dan memahami materi yang ada pada CD tersebut.

Satu cara yang tepat untuk mengatasi kendala-kendala tersebut adalah dengan fasilitas internet sebagai sarana pembelajaran atau biasa disebut dengan pembelajaran berbasis web. Pembelajaran berbasis web memungkinkan siswa untuk tetap dapat menimba ilmu di luar jam pelajaran sekolah. Alokasi waktu untuk mata pelajaran yang sedikit dapat diantisipasi dengan memberikan materi melalui internet (Mahmud, 2008). Kegiatan praktikum yang membutuhkan banyak waktu dapat dilakukan oleh siswa di rumah dengan panduan video proses praktikum yang diunggah oleh guru pada website. Selain itu proses pembelajaran akan lebih efisien dan fleksibel karena kegiatan pembelajaran dapat menyesuaikan ketersediaan waktu antara guru dan siswa. Kekurangan waktu belajar di sekolah dapat diantisipasi dengan memberikan materi yang diunggah melalui website sehingga siswa akan lebih aktif belajar (Sawant dan Shinde, 2012). Keuntungan lain dari pembelajaran berbasis web yaitu materi pelajaran dapat dibuka menggunakan perangkat selain komputer seperti android, tablet dan handphone yang telah memiliki aplikasi internet.

Beberapa penelitian menyatakan bahwa pembelajaran tatap muka yang dikombinasikan dengan pembelajaran berbasis web lebih efektif meningkatkan hasil belajar kognitif siswa (Wijaya, 2012; Papastergiou dan Gerodimos, 2012) dan keterampilan siswa (Cerra et al., 2013). Selain itu siswa mendapatkan umpan balik dari hasil evaluasi belajarnya berupa penjelasan setiap item pertanyaan secara langsung dan lengkap (Oliver, 2007). Selain itu, web yang diatur dengan baik dapat menciptakan tampilan materi pelajaran yang lebih menarik sehingga meningkatkan motivasi belajar siswa (Oliver, 2007; Erdogan, et al., 2008).

Pokok bahasan suhu dan kalor mengandung banyak materi dan kasus yang sulit dipahami jika cara menyampaikannya hanya menggunakan metode ceramah. Salah satunya konsep perubahan wujud zat. Titik lebur air berada pada suhu 0oC dan titik didihnya pada suhu $100 \mathrm{oC}$, materi ini sangat mudah dihafalkan siswa tetapi sangat sulit dipahami jika siswa tidak melihat secara langsung kasus tersebut. Begitu juga dengan materi lain seperti perpindahan kalor dan Azas Black.

Dalam tulisan ini, penulis menguraikan penelitian tentang pengaruh pembelajaran berbasis web terhadap motivasi dan hasil belajar siswa pada mata pelajaran fisika pokok bahasan suhu dan kalor.

\section{Metode Penelitian}

Penelitian ini menggunakan metode quasi eksperiman dengan tujuan untuk mengetahui pengaruh pembelajaran berbasis web terhadap motivasi dan hasil belajar siswa. Alamat website utama yang digunakan dalam pembelajaran yaitu http://suhudankalor.com (Kurniawan,et al, 2015). Variabel bebas dalam penelitian ini yaitu pembelajaran berbasis web, sedangkan sebagai variabel terikat yaitu motivasi dan hasil belajar.

Model penelitian quasi eksperimen ini menggunakan non-equivalent groups pretest-posttest experimental design. Kegiatan pembelajaran kelas eksperimen menggunakan metode perpaduan antara ceramah dan website, sedangkan kelas kontrol hanya menggunakan metode ceramah.

Tabel 1. Model Penelitian Kuasi Eksperimen yang Digunakan

\begin{tabular}{llll}
\hline Kelompok & Pretest & Perlakuan & Posttest \\
\hline Eksperimen & $\mathrm{R} 1$ & $\mathrm{X} 1$ & $\mathrm{R} 1$ \\
Kontrol & $\mathrm{R} 2$ & $\mathrm{X} 2$ & $\mathrm{R} 2$ \\
\hline
\end{tabular}

Keterangan :

R1 : Pelaksanaan pretest dan posttest kelas eksperimen

$\mathrm{R} 2$ : Pelaksanaan pretest dan posttest kelas kontrol

$\mathrm{X} 1$ : Pembelajaran dengan website

$\mathrm{X} 2$ : Pembelajaran tanpa website

Populasi pada penelitian ini yaitu seluruh siswa kelas X SMAN Paguyangan yang berjumlah 125 siswa. Teknik pengambilan sampel menggunakan puposif sampling. Jumlah sampel yang diambil sebanyak 48 siswa, dengan rincian 24 siswa pada kelas eksperimen dan 24 siswa pada kelas kontrol. Berdasarkan jenis kelamin, sampel dengan jenis kelamin perempuan berjumlah 17 siswa dan yang berjenis kelamin laki-laki berjumlah 7 siswa baik pada kelas eksperimen maupun kelas kontrol.

Data yang diperoleh dari penelitian ini adalah data kuantitatif yaitu skor sikap siswa dalam pelaksanaan pembelajaran atau skor motivasi belajar siswa dan skor tes hasil belajar siswa. Instrumen pengumpul data dalam penelitian ini adalah angket motivasi belajar siswa dengan 20 pertanyaan yang diisi sebelum kegiatan pembelajaran, lembar observasi pelaksanaan pembelajaran, dan tes hasil belajar (pretest dan posttest) dengan 10 soal multiple choice dan 5 soal uraian. Selain menggunakan 
angket motivasi belajar dan lembar observasi pelaksanaan pembelajaran, keaktifan siswa juga dikontrol melalui website. Melalui halaman admin guru dapat mengetahui frekuensi siswa membuka materi pada website yang selanjutnya sebagai dasar evaluasi setiap pertemuan.

Analisis data angket motivasi dan lembar observasi pelaksanaan pembelajaran menggunakan deskrptif persentase dengan tujuan untuk mengetahui skor motivasi belajar tiap siswa. Sedangkan peningkatan motivasi dan hasil belajar siswa dianalisis menggunakan uji t (Sugiyono, 2010).

\section{Hasil dan Pembahasan}

Website sebagai pendukung kegiatan pembelajaran melatih kemandirian siswa dalam menemukan dan menghubungkan konsep materi pelajaran. Siswa lebih aktif dalam mencari sumber-sumber materi secara online melalui link-link yang telah disediakan pada website. Teori belajar konstruktivisme mengungkapkan bahwa kegiatan pembelajaran yang baik ditandai dengan besarnya keaktifan siswa dalam menemukan dan membangun konsep. Guru hanya sebagai pendamping yang bertugas mengarahkan dan membimbing siswa pada saat proses pembelajaran di kelas. Pernyataan tersebut diperkuat oleh hasil penelitian Oliver (2007) yang menyatakan bahwa pembelajaran yang terpusat pada siswa lebih meningkatkan motivasi belajar dan sikap positif dalam kegiatan pembelajaran. Menurut Yen, et al. (2010) salah satu strategi yang tepat untuk melibatkan siswa dalam kegiatan pembelajaran yaitu pembelajaran berbasis website.

Berdasarkan hasil observasi sikap siswa ketika proses pembelajaran berlangsung, setiap aspek sikap positif yang diamati cenderung mengalami kenaikan pada setiap pertemuan. Semangat belajar siswa ditunjukan oleh sikap siswa yang berusaha menjawab setiap pertanyaan atau soal yang diajukan oleh guru dan selalu memperbaiki jika jawaban yang disampaikan kurang tepat. Pendirian siswa ditandai dengan sikap tegas yang ditunjukan siswa ketika menjawab pertanyaan tertulis maupun lisan. Kemandirian siswa ditunjukan oleh sikap siswa ketika mengerjakan latihan soal, pretest ataupun posttest. Kemauan belajar keras ditunjukan oleh kedisiplinan siswa dalam mencatat setiap materi maupun dalam mengerjakan tugas. Ketekunan dan keberanian siswa ditunjukan oleh pemanfaatan waktu belajar sebaik-baiknya dan konsentrasi dalam belajar serta berani menjawab pertanyaan yang diajukan oleh teman ataupun guru. Diagram peningkatan sikap positif siswa ketika proses pembelajaran tersaji pada Gambar 1.

Untuk mendukung hasil observasi, pada akhir pertemuan diberikan angket terbuka tentang tanggapan siswa terhadap materi yang disajikan dalam website. Dari 24 siswa yang ada pada kelas eksperimen hanya 15 siswa yang bersedia mengisi angket. Hasil angket menunjukan bahwa 13 dari 15 siswa menyatakan sangat setuju terhadap pernyataan "materi dirancang sedemikian rupa sehingga menarik dan melibatkan saya aktif mempelajarinya", 1 siswa menyatakan setuju dan hanya 1 siswa menyatakan kurang setuju seperti ditunjukan pada Gambar 2.

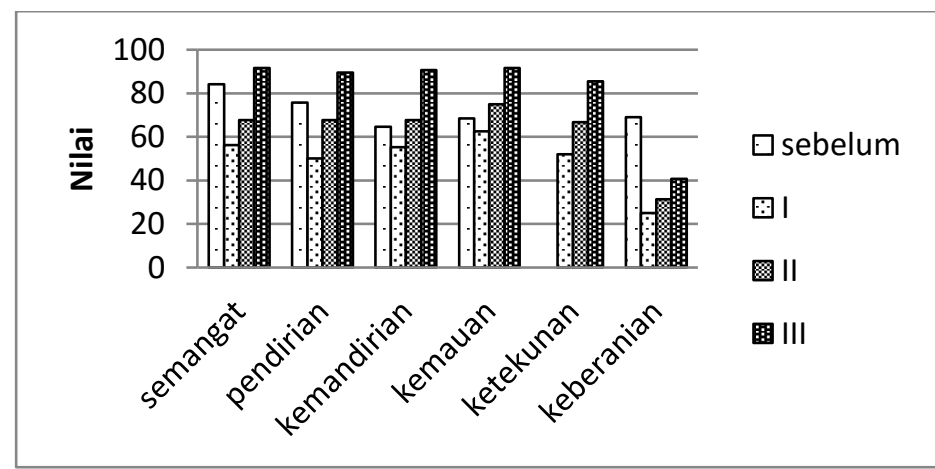

Gambar 1. Peningkatan sikap positif siswa kelas eksperimen ketika kegiatan pembelajaran pada setiap pertemuan (pertemuan I, II dan III)

Ada beberapa kemungkinan siswa tertarik dengan materi pembelajaran berbasis website. Pertama, contoh-contoh peristiwa ataupun prosesnya yang berhubungan dengan materi pelajaran dapat dilihat dengan jelas melalui video dan animasi yang diunggah pada website. Hal ini sesuai dengan hasil penelitian Rosen (2009) yang menyatakan bahwa video atau animasi dalam pembelajaran dapat meningkatkan motivasi siswa. Siswa lebih mudah menyerap dan mengingat informasi yang diperoleh melalui video atau animasi jika dibandingkan dengan gambar atau teks.

Kedua, sub sub materi tersusun secara sistematis sehingga memudahkan siswa dalam membaca dan memahami materi. Hal tersebut dibuktikan dengan hasil angket yang mengungkapkan bahwa 14 siswa menyatakan sangat setuju dan 1 siswa menyatakan setuju pada pernyataan "materi dalam pembelajaran berbasis web ini disusun sedemikian rupa sehingga mudah diikuti".

Ketiga, akhir setiap sub materi terdapat evaluasi yang hasilnya dapat langsung diketahui oleh siswa setelah selesai mengerjakan dan setiap soal yang salah dijawab ada timbal balik penyelesaian yang tepat. Hal ini sesuai dengan pendapat Palmer (2005) bahwa motivasi siswa dapat dibangun melalui pemberian hadiah (reward) pada setiap pembelajaran bagi siswa yang berhasil mencapai tujuan pembelajaran. Hadiah tersebut selain berupa benda dapat juga berupa pujian atau nilai hasil belajar yang dibagikan. 


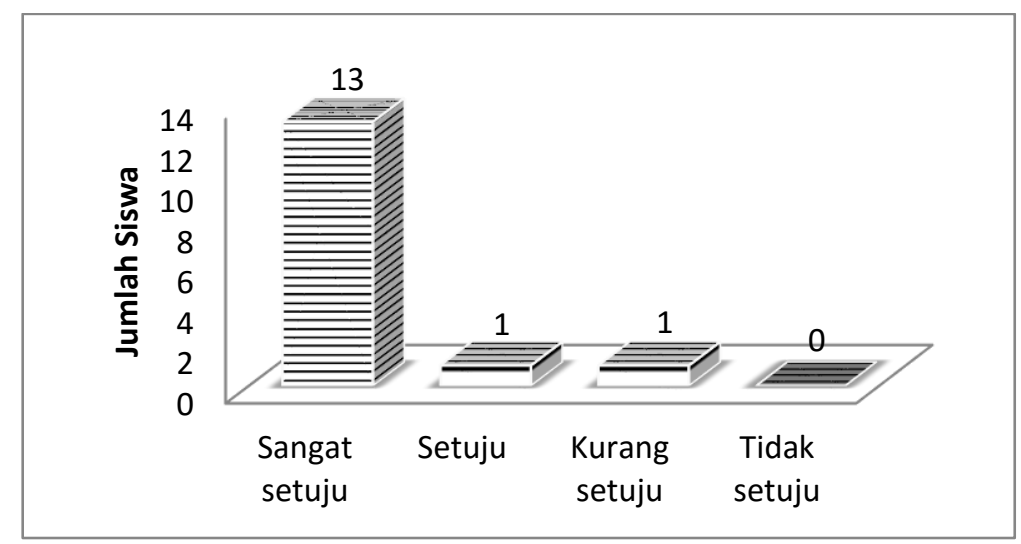

Gambar 2. Tanggapan siswa terhadap pernyataan "materi dirancang menarik sehingga saya aktif mempelajarinya"

Sikap positif siswa dalam belajar juga dapat diketahui dari frekuensi siswa membuka materi dan mengerjakan evaluasi yang terdapat pada website tersebut. Data yang terekam pada halaman administrator menunjukan bahwa frekuensi membuka website terbanyak yaitu 12 kali dan paling sedikit yaitu 1 kali seperti ditunjukan pada Gambar 3.

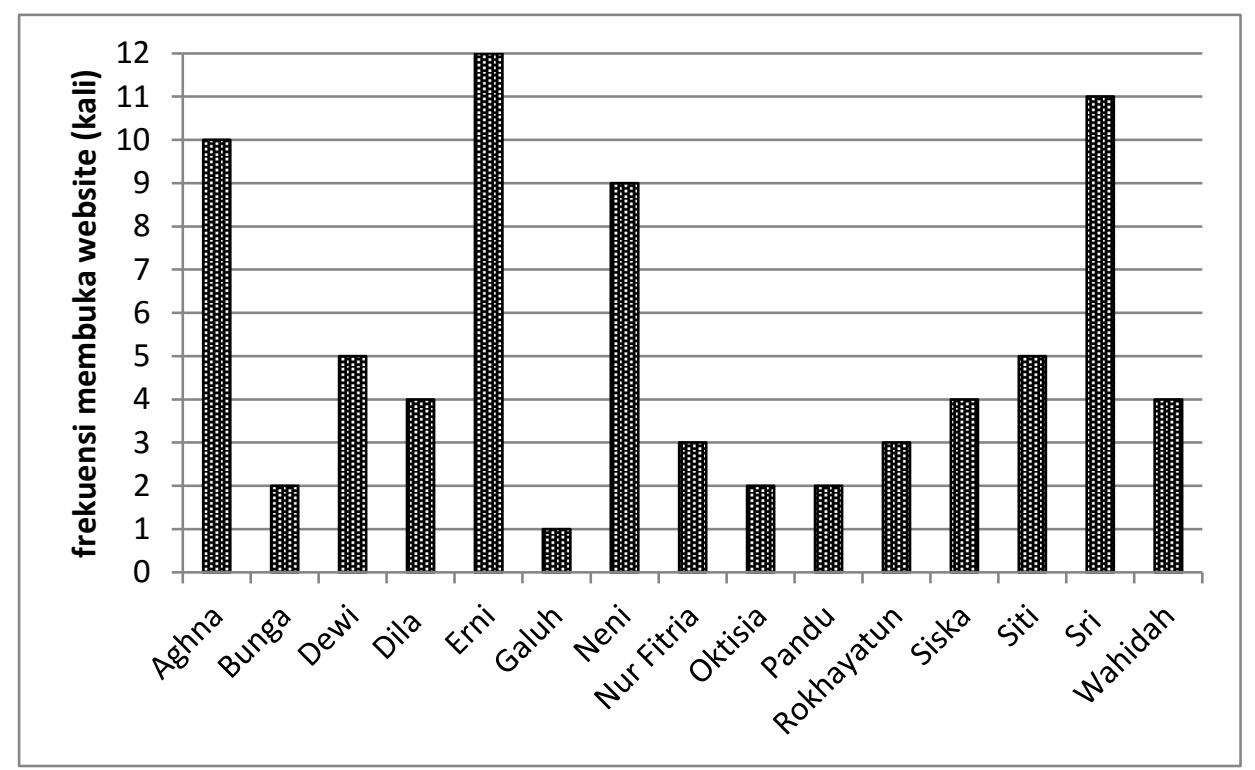

Gambar 3. Frekuensi membuka website per siswa

Berdasarkan jenis kelamin siswa perempuan lebih sering membuka website dibandingkan dengan siswa laki-laki. Hanya 1 siswa yang aktif membuka website dari 7 siswa laki-laki sedangkan untuk siswa perempuan ada 14 siswa yang aktif dari 17 siswa perempuan yang ada. Menurut Erdogan, et al. (2008) dalam hasil penelitiannya menyatakan bahwa siswa perempuan lebih aktif dan berhasil pada pembelajaran berbasis web jika memiliki fasilitas komputer dan jaringan internet yang memadai.

Berbeda dengan hasil penelitian Paris (2004) yang menyatakan bahwa antara siswa laki-laki dan perempuan tidak ada perbedaan sikap yang signifikan pada saat mengikuti kegiatan pembelajaran berbasis e-learning. Sedangkan penelitian lain (Kay, 2007; Liaw dan Huang, 2011) menyatakan bahwa siswa laki-laki cenderung lebih lebih aktif terhadap pembelajaran berbasis teknologi jika dibandingkan dengan siswa perempuan.

Ada beberapa kemungkinan yang perlu diteliti lebih lanjut tentang kenapa siswa laki-laki pada penelitian ini cenderung lebih pasif daripada siswa perempuan. Hal-hal yang perlu diteliti tersebut antara lain, (1) apakah fasilitas komputer dan jaringan internet yang mereka miliki memadai atau tidak, (2) apakah mereka sudah pernah mendapatkan strategi pembelajaran berbasis web atau belum, (3) apakah mereka sudah familier dengan internet atau tidak.

Peningkatan motivasi siswa dalam kegiatan pembelajaran juga disebabkan oleh pembelajaran berbasis web merupakan strategi pembelajaran yang belum pernah digunakan di SMAN Paguyangan. Hal ini didasarkan pada hasil observasi dan wawancara kultural kepada 26 siswa kelas X pada penelitian pendahuluan. Mereka mengungkapkan bahwa guru hanya menggunakan buku teks dan LKS ketika pembelajaran dan tidak pernah diperintahkan untuk membuka website tertentu yang terkait dengan materi. Menurut Yen, et al. (2010) strategi pembelajaran baru yang digunakan untuk setiap pokok bahasan dapat meningkatkan ketertarikan siswa. 
Efektifitas proses pembelajaran dalam meningkatkan hasil belajar diketahui berdasarkan perbandingan nilai pretest dan posttest siswa di kelas eksperimen maupun kelas kontrol menggunakan uji t. Nilai pretest dan posttest kedua kelas tersebut dapat dilihat pada Gambar 4.

Gambar 4 menunjukan perbedaan rerata hasil belajar siswa di kedua kelas uji coba setelah mengikuti kegiatan pembelajaran. Rerata nilai posttest kelas eksperimen 74,03 dan kelas kontrol 71,25. Analisis perbedaan hasil belajar menggunakan uji t didapatkan harga thitung sebesar 1,445. Harga ini lebih kecil dari tabel yaitu 1,67 dengan taraf kesalahan 5\% dan derajat kebebasan 46. Hal ini menunjukan tidak ada perbedaan hasil belajar antara kelas eksperimen dan kelas kontrol, yang berarti konten pembelajaran berbasis website tidak berpengaruh terhadap peningkatan hasil belajar siswa secara keseluruhan.

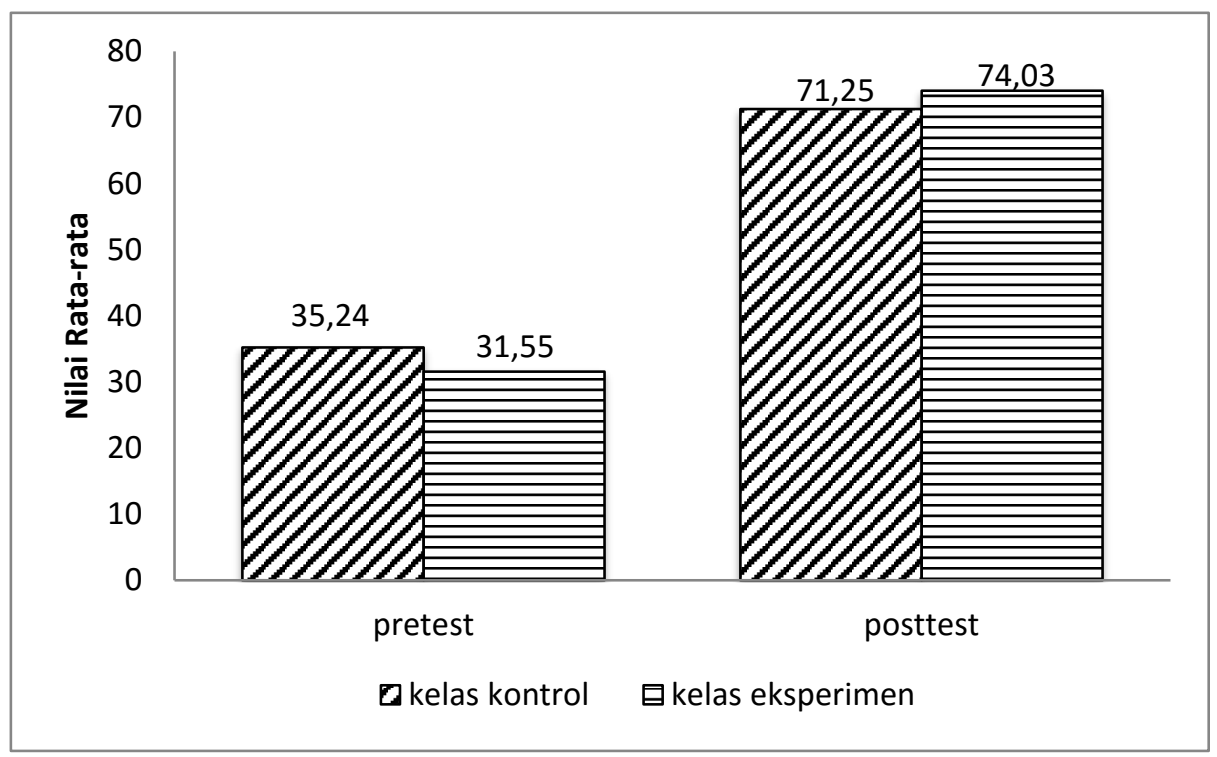

Gambar 4. Rerata nilai pretest dan posttest kelas kontrol dan kelas eksperimen

Temuan tersebut sesuai dengan hasil penelitian Bennett (2002) yang menyatakan bahwa tidak ada perbedaan hasil belajar antara kelas yang menggunakan metode pembelajaran berbasis web dengan kelas yang menggunakan metode ceramah. Berbeda dengan hasil penelitian lain yang mengungkapkan bahwa ada perbedaan hasil belajar yang signifikan antara kelas dengan pembelajaran berbasis web dan berbasis ceramah pada mahasiswa ilmu komunikasi (Oliver, 2007), pada kelas teknik mata kuliah menggambar mekanik (Cerra et al., 2013), dan kelas olahraga pokok bahasan bola basket (Papastergiou dan Gerodimos, 2012).

Penelitian yang dilakukan oleh Oliver (2007), Papastergiou dan Gerodimos (2012), dan Cerra et al. (2013) kalau dicermati ternyata menggunakan mahasiswa sebagai objek penelitian. Hal tersebut tentu berbeda dengan penelitian yang menggunakan siswa SMA kelas X sebagai objek penelitiannya. Menurut Erdogan et al. (2008) dalam hasil penelitiannya mengatakan bahwa faktor umur memiliki pengaruh yang signifikan terhadap keberhasilan pembelajaran berbasis web. Dalam hal ini, selisih umur antara siswa kelas X (rata-rata 15 tahun) dan mahasiswa (rata-rata 21 tahun) yaitu sebesar 7 tahun. Mereka masih memerlukan bimbingan dalam belajar jika dibandingkan dengan mahasiswa yang sudah dapat belajar secara mandiri.

Faktor penyebab lain yaitu frekuensi siswa membuka website seperti ditampilkan pada Gambar 3. Jika dicocokkan dengan data nilai posttest menunjukan ada kecenderungan siswa yang lebih sering membuka website memperoleh nilai posttest yang lebih tinggi. Siswa yang membuka website lebih dari 4 kali, rata-rata mendapatkan nilai 73-93. Selain itu, siswa yang masih memperoleh nilai rendah atau di bawah rata-rata merupakan siswa yang hanya membuka website sebanyak 2 kali. Dari temuan ini dapat dinyatakan bahwa agar hasil belajar siswa lebih optimal pada pembelajaran berbasis web maka harus ada peraturan atau regulasi yang mendorong siswa membuka dan mempelajari materi pada website dengan frekuensi yang ditetapkan pada awal pembelajaran.

Oliver (2007) berpendapat bahwa pembelajaran berbasis web membebankan tanggung jawab yang lebih pada siswa daripada metode pembelajaran ceramah. Dalam banyak kasus pembelajaran berbasis web yang direduksi menjadi bantuk website atau animasi multimedia memungkinkan untuk pengembangan konten dan evaluasi materi. Oleh karena itu, komunikasi dua arah antara komputer dan siswa dapat berkontribusi untuk kemajuan siswa dalam belajar. Dengan cara ini siswa akan termotivasi untuk memecahkan masalah mereka.

Jika ditinjau dari signifikansi peningkatan nilai rata-rata pretest dan posttest, berdasarkan hasil uji t kelas eksperimen mengalami peningkatan yang lebih signifikan yaitu 26,661 jika dibandingkan dengan kelas kontrol yang hanya 20,103. Hal ini mengindikasikan bahwa konten pembelajaran berbasis website berpengaruh lebih besar dalam meningkatkan hasil belajar jika dibandingkan dengan konten pembelajaran yang biasa digunakan. Selain itu, frekuensi siswa pada kelas eksperiman lebih banyak daripada kelas control dalam hal perolehan nilai di atas rata-rata seperti disajikan pada Gambar 5. 


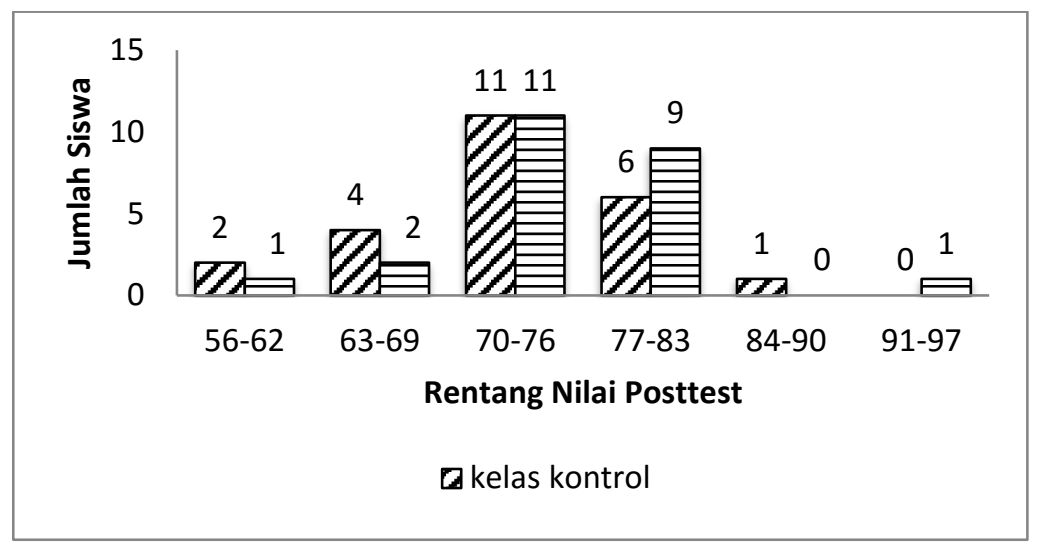

Gambar 5. Sebaran nilai posttest kelas kontrol dan kelas eksperimen

Berdasarkan Gambar 5 diketahui bahwa 21 siswa pada kelas eksperimen mendapat nilai lebih besar atau sama dengan 70 dengan rincian 11 siswa mendapat nilai 70-76, 9 siswa mendapat nilai 77-83 dan 1 siswa mendapat nilai 93. Ada 3 siswa pada kelas ini yang mendapat nilai di bawah 70 dengan rincian 2 siswa mendapat nilai 66,67 dan 1 siswa mendapat nilai 60,00 . Sedangkan pada kelas kontrol hanya 18 siswa yang mendapat nilai lebih besar atau sama dengan 70 dengan rincian 11 siswa mendapat nilai 70-76, 6 siswa mendapat nilai 77-83 dan 1 siswa mendapat nilai 86. Ada 6 siswa pada kelas ini yang mendapatkan nilai di bawah 70 dengan rincian 4 siswa mendapat nilai 63-69 dan 2 siswa masing-masing mendapat nilai 56,67 dan 60,00. Singkatnya, menurut hasil yang diperoleh dapat dikatakan bahwa lebih banyak siswa pada kelas eksperimen lulus jika dibandingkan dengan kelas kontrol. Hasil ini dapat menjadi alasan bahwa konten pembelajaran dan evaluasi materi berbasis web pada mata pelajaran fisika perlu dikembangkan terus.

Peningkatan hasil belajar yang signifikan juga tidak terlepas dari motivasi belajar siswa yang tinggi. Hal ini dibuktikan dengan hasil angket yang mengungkapkan bahwa $80 \%$ siswa mengisi kolom "Sangat Setuju" pada pernyataan "Materi dirancang sedemikian rupa sehingga menarik dan melibatkan saya aktif dalam mempelajarinya". Hasil ini didukung oleh penelitian sebelumnya yang menyimpulkan bahwa hasil belajar peserta didik dapat meningkat seiring dengan motivasi belajar yang tinggi (Puspitorini, et al., 2014).

Muse (2003) berpendapat bahwa tidak semua pembelajaran berbasis web dapat diterapkan pada seluruh siswa tergantung karakteristik mereka. Motivasi diri berupa rasa membutuhkan atas materi pelajaran dan ketekunan dalam belajar menjadi faktor utama dalam keberhasilan pembelajaran berbasis web. Kebutuhan siswa atas materi pelajaran biasanya akan naik ketika mendekati kelulusan, sehingga pembelajaran dengan metode apapun akan berhasil jika diterapkan pada kelas tersebut. Selain itu menurut Selim (2007) faktor pendukung lain dalam keberhasilan pembelajaran berbasis web adalah fasilitas komputer dan jaringan internet yang memadai.

\section{Simpulan}

Berdasarkan temuan hasil penelitian dapat disimpulkan bahwa pembelajaran berbasis web dapat meningkatkan motivasi dan hasil belajar siswa pada pokok bahasan suhu dan kalor. Perlu dilakukan penelitian lebih lanjut untuk mengetahui ranah kognitif apa saja yang mengalami peningkatan atau penurunan jika menggunakan pembelajaran berbasis $w e b$.

\section{Daftar Pustaka}

Arikunto, S. 2006. Prosedur Penelitian. Jakarta: PT. Rineka Cipta

Bennett, G. 2002. Web-based Instruction in Sport Management. Sport Management Review, 5, 45-68

Cerra, P.P. et al. 2013. Can Interactive Web-based CAD Tools Improve the Learning of Engineering Drawing? A Case Study. Journal Science Education Technology, doi 10.1007/s10956-01309471-7

Erdogan, Y., Bayram, S. dan Deniz, L. 2008. Factors That Influence Academic Achievement And Attitudes In Web Based Education. International Journal of Instruction, 1(1).

Kay, R. 2007. Gender Differences in Computer Attitudes, Ability, and Use in the Elementary Classroom. The Literacy and Numeracy Secretariat University of Ontario

Kurniawan, F.A., Sulhadi dan Yulianto, A. 2015. Pengembangan Bahan Ajar Berbasis Web pada Mata Pelajaran Fisika Pokok Bahasan Suhu dan Kalor. Indonesian Journal of Applied Physics, 5 (2).

Liaw, S.S. dan Huang, H.M. 2011. A Study of Investigating Learners Attitudes Toward E-Learning. International Conference on Distance Learning and Education, IPCSIT, 12

Mahmud, R. 2008. "Pembelajaran Berasaskan Web". Dalam Isjoni dan Firdaus (Ed.), Pembelajaran Terkini: Perpaduan Indonesia-Malaysia. Yogyakarta: Pustaka Pelajar. 73-83 
Muse, H.E. 2003. The Web-Based Community College Student: An Examination of Factors that Lead to Success and Risk. Internet and Higher Education, 6 (3), 241-261

Oliver, R. 2007. Engaging first year students using a Web-supported inquiry-based learning setting. High Education, 55, 285301 .

Palmer, D. 2005. A Motivational View of Constructivist-informed Teaching. International Journal of Science Education, 27 (15), 1853-1881

Papastergiou, M. dan Gerodimos, V. 2012. Can learning of basketball be enhanced through a web-based multimedia course? An experimental study. Education Information Technology (2013), 18, 459-478, doi 10.1007/s10639-012-9186-z

Paris, P.G. 2004. E-Learning: A Study on Secondary Students' Attitudes towards Online Web Assisted Learning. International Education Journal, 5 (1)

Puspitorini, R., Prodjosantoso, A.K., Subali, B. \& Jumadi. 2014. Penggunaan Media Komik dalam Pembelajaran IPA untuk Meningkatkan Motivasi dan Hasil Belajar Kognitif dan Afektif. Cakrawala Pendidikan, XXXIII (3).

Rosen, Y. 2009. The effects of an animation-based on-line learning environment on transfer of knowledge and on motivation for science and technology learning. Journal of Educational Computing Research, 40(4) 451-467.

Sawant, B.S. dan Shinde, S.P. 2012. A Study of Effect of Web-Based Education Environment in Schools: With special reference to Satara District. International Journal of Soft Computing and Engineering (IJSCE) Vol. 1

Sugiyono. 2010. Statistika Untuk Penelitian. Bandung: Alfabeta.

Sutarman, A. 2016. Pemanfaatan Pembelajaran Berbasis Komputer Model CD Interaktif Tutorial untuk Meningkatkan Hasil Belajar. Jurnal Penelitian dan Pembelajaran IPA, 2 (1).

Wijaya, M. 2012. Pengembangan Model Pembelajaran e-Learning Berbasis Web dengan Prinsip e-Pedagogy dalam Meningkatkan Hasil Belajar. Jurnal Pendidikan Penabur, 11 (11)

Yen, H.C., Tuan, H.L. dan Liao, C.H. 2010. Investigating the Influence of Motivation on Students' Conceptual Learning Outcomes in Web-based vs. Classroom-based Science Teaching Contexts. Reseach Science Education, 41, 211-224, DOI $10.1007 / \mathrm{s} 11165-009-9161-\mathrm{x}$ 